\title{
Interest Group Survival: Shared Interests Versus Competition for Resources
}

\author{
Donald P. Haider-Markel \\ University of Wisconsin-Milwaukee
}

\begin{abstract}
Population ecology theory on interest group populations is examined to determine the implications for group membership levels in the states. Using the assumptions of the competitive exclusion principle, it is hypothesized that relatively new interest groups should not directly compete for space, but should instead have a positive influence on each other's membership levels. A group's membership level should also be a function of space, energy, and political mobilization factors. Multiple regression analysis is applied to a fifty-state data set using the membership levels of five gay and lesbian interest groups as dependent variables. The hypotheses are confirmed-interest groups avoid direct competition for space by adapting into different issue niches. The results of these findings for a population ecology theory of interest groups are discussed along with directions for future research.
\end{abstract}

\section{SURVIVING AS AN ORGANIZED INTEREST}

In order to survive, an organization must effectively exploit the resources in its environment. Because many organizations are dependent on the same resources as other, similar, organizations, they must find a way to share resources or eliminate other organizations through competition. In the case of interest groups working toward the same goal or collective good, however, competition seems illogical. How do interest groups resolve this conflict between selfpreservation and the achievement of a collective good?

Lowery and Gray (1995) provide at least part of the answer in their analysis of interest groups at the aggregate level. They draw on biological concepts from population ecology theory to explain the number of groups within specific issue areas, but they do not use the theory to explain how or why membership levels in a group might vary across political jurisdictions. Because population ecology theory outlines the nature of an ecosystem where groups within an issue area must struggle for resources and members to survive, the purpose here is to test the implications of the theory for the membership levels of interest groups within an issue area. I review population ecology theory and other literature addressing

An earlier version of this article was presented at the 1995 annual meeting of the American Political Science Association. I would like to thank Kenneth J. Meier and Lael Keiser for comments on earlier drafts of this article. The data and documentation necessary to replicate this analysis are available upon request from the author.

The Journal of Politics, Vol. 59, No. 3, August 1997, Pp. 903-12

(C)1997 by the University of Texas Press, P.O. Box 7819, Austin, TX 78713-7819 
group membership levels, develop hypotheses concerning competition, space, and energy, and test the hypotheses on the membership levels of five national gay and lesbian interest groups using a fifty-state data set. The findings and their implications are discussed in light of population ecology theory and research on interest groups more generally.

\section{The Population Ecology Theory of Interest Group Systems}

Lowery and Gray $(1995,5)$ invite us to consider the interest group population of a state as an ecological system where species live, reproduce, and die as they struggle for resources. They argue that the population ecology models employed in biology can be used to investigate such organizations as interest groups, because organizational populations are also constrained by their environments (see also Gray and Lowery 1996; Hannan and Carroll 1992; Hannan and Freeman 1989). Competition is the main concept of population ecology theory, and the primary assumption of competition is that species, and members of species, attempt to avoid competition by evolving into ecological niches. If these niches overlap, species will "partition access" to the overlapping resource so that each can survive. Biologists refer to this process as the competitive exclusion principle.

Several important points stem from the assumptions of the competitive exclusion principle. First, and compatible with interest group research, species avoid competition by developing an ecological niche (Lowery and Gray 1995, 9; see also Browne 1990; Gray and Lowery 1996). Second, individual groups within an issue area develop issue niches to avoid directly competing with each other in the same way species avoid competition with other species (Lowery and Gray 1995, 10; see also Browne 1990; Gray and Lowery 1996). Eventually, however, issue niches may be limited by space, or the number of potential constituents; and groups will be forced to compete directly. Third, interest groups also need energy to survive. Lowery and Gray (1995, 11-12) define energy as the potential government goods or services that could be obtained by the group through lobbying efforts. Energy can stem from positive or negative forces but is best described as "how active the government is now or potentially will be in the field impacting on . . . each type of group."1

The concepts and assumptions of population ecology theory suggest that interest groups within an issue area should strategically focus on narrow issues rather than general issues to avoid competition for members. If groups are working on similar issues in separate issue niches, their membership levels will be positively related for two reasons: first, the relationship between space (potential members) and the number of groups is positive, and second, groups will partition shared space, perhaps even to the extreme of sharing information and building

\footnotetext{
${ }^{1}$ In a similar manner, Brown (1989) argues that favorable public policy can help to mobilize potential constituents.
} 
coalitions. If groups are not focusing on similar issues, space is less of a problem and membership levels will not be related. Furthermore, if space becomes limited, groups will begin to compete directly and their membership levels will be negatively related.

If space is still abundant during the observation period, therefore, gay and lesbian group membership levels should be positively related. Few existing national gay and lesbian interest groups were formed more than fifteen years ago, and gay groups did not proliferate until the 1980s. Given this short time frame, lesbian and gay groups should have developed separate issue niches to avoid direct competition for space, but are unlikely to have maximized their space. Lesbian and gay interest group membership levels, therefore, should be positively related.

\section{Individual Level Factors}

Population ecology theory focuses on factors at the aggregate level even though individual level socioeconomic factors can influence a person's decision to join an interest group. Rosenstone and Hansen (1993, 31-32), for instance, argue that those of higher socioeconomic status will not only have more time and resources to participate politically, but their status also make them more likely targets for mobilization by groups (see also Leighley 1995). If socioeconomic factors such as income and education influence individual decision-making, one might also suspect that states with higher levels of income and education will have more persons involved with interest groups. In population ecology terms, an educated and wealthy population should make it easier for interest groups to use the "space" in which they live.

\section{VARIABLES: OPERATIONALIZATION AND MEASUREMENT}

\section{Dependent Variables}

At the national level, the gay and lesbian interest group system is surprisingly diverse. Groups such as the National Gay and Lesbian Task Force (NGLTF) and the Human Rights Campaign (HRC) are large and well funded, while groups such as Lambda Legal Defense and Education Fund (LLDEF), Gay and Lesbian Parents Coalition International (GLPCI), and the Gay and Lesbian Victory Fund (GLVF) are supported by relatively small membership rolls. In order to have a diverse collection of groups, I have selected groups that are composed mostly of gay and lesbian members, groups that focus on litigation (LLDEF, and HRC to some extent), groups that rely largely on lobbying and/or public education (NGLTF, GLPCI, and HRC), and groups that operate primarily as PACs 
(GLVF). ${ }^{2}$ The membership level of each of these five groups is measured as the number of members per 100,000 state population. ${ }^{3}$

\section{Independent Variables: I. Population Ecology Variables}

Competition. If the competitive exclusion principle is correct concerning interest group behavior, competition between lesbian and gay groups for members should lead to a partitioning or sharing of resources. Subsequently, the membership levels of gay and lesbian groups should be positively related. Competition and the resulting partitioning of resources is measured as the summed membership per 100,000 state population of the four lesbian and gay groups not being examined as the dependent variable in each model. For example, in the model explaining membership in the NGLTF, the summed membership of LLDEF, HRC, GLPCI, and GLVF is used as an independent variable.

Space. Because space, the area in which interest groups live, is defined as a group's potential constituency, a measure of the gay and lesbian population is needed. While no simple measure exists, the 1990 census asked respondents if they lived with a partner to whom they were not married. The resulting data are separated by partnerships wherein both members are female and partnerships wherein both members are male. My measure of the lesbian and gay population, therefore, is the number of same-gender unmarried partner households per 100,000 state population. ${ }^{4}$ Potential Constituency is expected to be positively related to membership levels in gay and lesbian interest groups. While this measure counts only those homosexuals in a relationship, living with a partner, and willing to admit it, the measure has clear face validity and is the best available measure of gay and lesbian population (see Haider-Markel and Meier n.d.; Wald, Button, and Rienzo 1996, 1170).

Because state economic development and diversity influence the number of groups overall (Hunter, Wilson, and Brunk 1991; Lowery and Gray 1993, 1994), the economic development in a community of potential interest group constituents should influence the membership levels of interest groups. Greater economic development in the gay community should create a larger pool of individuals that have the time, resources, and the incentive to participate in collective action. The economic development of the lesbian and gay community is measured as

\footnotetext{
${ }^{2}$ The selection of groups was limited by data availability. Many groups I contacted, including The Log Cabin Federation, Parents and Friends of Lesbians and Gays, ACT UP, Queer Nation, The Lesbian Avenger Civil Rights, Radical Fairies, Dignity USA, AIDS Action Council, Gay and Lesbian Advocates and Defenders, and the Gay and Lesbian Alliance Against Defamation, would not or could not provide state membership figures. The groups providing figures, however, are generally representative of the lesbian and gay interest group universe.

${ }^{3}$ Membership data were provided to the author by each interest group.

${ }^{4}$ Data are from U.S. Bureau of the Census $(1990,195-200$; see notes to Table 146 for a full definition).
} 
the summed number of gay businesses, bars, and newspapers per one million state population. ${ }^{5}$

Energy. The energy interest groups need to survive comes largely from the actual or potential benefits available to the group from government (Lowery and Gray 1995). To account for energy, therefore, we must measure government action or potential action on gay and lesbian issues. Government activity on gay issues is examined by measuring the existence of antidiscrimination laws for gays and lesbians in the areas of public employment, public accommodations, private employment, education, housing, credit, and union practices. Each of the seven policies was measured by noting the jurisdiction covered (city, county, or state) and summing the population of each jurisdiction covered as a percentage of the total state population covered by the law (see Haider-Markel and Meier 1996). ${ }^{6}$ To illustrate the measure, Alaska does not have a state law banning discrimination based on sexual orientation in public employment, but its largest city (Anchorage) does. Given the population of Alaska and Anchorage, 41.2 percent of Alaska's population is protected from sexual orientation discrimination in public employment.

The percentage of the population covered by each law was summed to obtain one measure of state policy toward lesbians and gays, which is expected to be positively related to interest group membership levels. While favorable public policy may mobilize potential constituents as shown by Brown (1989) and Hansen (1985), group members are also a potential resource that interest groups can use to influence public policy (Haider-Markel and Meier 1996). I use the measure here simply to control for the effects of energy in the model and leave the causal order for future research.

Another possible measure of energy is the salience of gay and lesbian issues. High issue salience may indicate both more government activity and more interest group activity. Furthermore, because salient issues increase citizen participation (see Hansen 1985, 83; Meier 1988, 30), it is logical to hypothesize that this participation may include joining interest groups. As the salience of gay and lesbian issues increases, I expect that membership in lesbian and gay interest groups will also increase. Issue salience is measured as the number of newspaper articles on gay and lesbian issues per 100,000 state population between 1985 and 1993, as found on the Nemsbank Electronic Information System. ${ }^{7}$

\footnotetext{
${ }^{5}$ This measure was created by counting the number of gay businesses, bars, and newspapers listed in the Damron Road Atlas (3d ed.) for each state. This list was supplemented by listings in Odysseus 1992. Both are publications of the Damron Company and are the most comprehensive sources for contacts among gays and lesbians.

${ }^{6}$ City, county, and state laws are those listed by the National Gay and Lesbian Task Force (1993) and population data are from the U.S. Bureau of the Census (1992). As of May 1993 there were 140 laws nationwide.

${ }^{7}$ This system is an electronic index of major U.S. newspapers. It contains over 900,000 articles that can be referenced by key-words and listed by state. I used the key-words gay, lesbian, and homosexual.
} 


\section{Independent Variables: II. Individual Level Factors}

Income and education have been shown to influence the individual decision to join an interest group (see Leighley 1995 for a summary). Because the relationships are significant at the individual level, and individual decisions will influence the overall membership levels of groups, I hypothesize that higher income and education levels in a state will lead to higher membership levels in gay and lesbian interest groups (see Hansen 1985 for a similar argument). ${ }^{8}$ The high correlation between income and education levels forced me to standardize the measures by transforming each measure by its natural logarithm and then assigning each variable a mean of zero and a standard deviation of one. The standardized measures were then summed to create a single measure. ${ }^{9}$

\section{STRategy OF ANALYSIS}

Membership in each of the five gay and lesbian groups is modeled separately, and standard regression diagnostics are used to test for collinearity problems and influential data points. ${ }^{10}$ Because the results are compared across groups, the same variables are used in each model. Most of the variables used in this analysis are highly skewed, and preliminary analysis suggested that some of the relationships are nonlinear, leading me to transform each variable by its natural logarithmic function. Logging each of the variables allows the results to be interpreted as elasticities and should provide unbiased regression estimates (Tufte 1979).

\section{RESULTS AND ANALYSIS}

The results for each model are shown in Table 1 and mostly support the hypotheses developed from population ecology theory. Each model predicts membership in the lesbian and gay groups fairly well, leaving little variance to explain in the dependent variables. ${ }^{11}$ The regression coefficients for each variable can be interpreted as the percent increase in a group's membership for a one percent increase in the independent variable, controlling for the other independent variables.

Membership in the National Gay and Lesbian Task Force (NGLTF), Lambda Legal Defense and Education Fund (LLDEF), and the Human Rights Campaign

\footnotetext{
${ }^{8}$ Education is measured as the percentage of the state's population that are college graduates, while income is measured as per capita income. Data are from L.S. Bureau of the Census (1992).

${ }^{9}$ In my preliminary analysis, other factors were controlled for including urbanization, region, and political culture. None of these factors was significant, nor did any statistically improve the explanation level of the models.

${ }^{10}$ Regression diagnostics include studentized residuals, Hat Diagonal, and Cook's D.

${ }^{11}$ Regression diagnostics reveal that Hawaii and Mississippi are the most poorly predicted by the independent variables. Adding dummy variables for these states improves the overall fit of the models, but I can offer no theoretical reason as to why these states are so poorly predicted.
} 
TABLE 1

Population Ecology Model.s: Determinants of Membership

LEVELS IN GAY AND LESBIAN INTEREST GROUPS

\begin{tabular}{|c|c|c|c|c|c|}
\hline Independent Variables & $\begin{array}{l}\text { NGLTF } \\
\text { Members }\end{array}$ & $\begin{array}{l}\text { LLDEF } \\
\text { Members }\end{array}$ & $\begin{array}{c}\text { HRC } \\
\text { Members }\end{array}$ & $\begin{array}{c}\text { GLVF } \\
\text { Members }\end{array}$ & $\begin{array}{c}\text { GLPCI } \\
\text { Members }\end{array}$ \\
\hline \multicolumn{6}{|l|}{ Competitive exclusion } \\
\hline $\begin{array}{l}\text { Summed Membership } \\
\text { of other groups }\end{array}$ & $\begin{array}{l}.33^{* *} \\
(.12)\end{array}$ & $\begin{array}{l}.35^{* *} \\
(.17)\end{array}$ & $\begin{array}{l}.35^{* * *} \\
(.16)\end{array}$ & $\begin{array}{r}.46^{*} \\
(.23)\end{array}$ & $\begin{array}{c}.08 \\
(.19)\end{array}$ \\
\hline \multicolumn{6}{|l|}{ Space variables } \\
\hline Potential Constituency & $\begin{array}{l}.29^{* *} \\
(.12)\end{array}$ & $\begin{array}{l}.40^{* *} \\
(.16)\end{array}$ & $\begin{array}{l}.51^{* *} \\
(.15)\end{array}$ & $\begin{array}{l}.54^{* *} \\
(.21)\end{array}$ & $\begin{array}{l}.87^{* *} \\
(.17)\end{array}$ \\
\hline Summed Gay Institutions & $\begin{array}{c}.96 \\
(8.30)\end{array}$ & $\begin{array}{l}-5.40 \\
(10.95)\end{array}$ & $\begin{array}{l}11.37 \\
(9.56)\end{array}$ & $\begin{array}{l}35.11^{* *} \\
(13.58)\end{array}$ & $\begin{array}{c}-36.33^{* *} \\
(11.38)\end{array}$ \\
\hline \multicolumn{6}{|l|}{ Engery variables } \\
\hline Anti-discrimination Policy & $\begin{array}{l}.08^{* *} \\
(.02)\end{array}$ & $\begin{array}{c}.07^{*} \\
(.03)\end{array}$ & $\begin{array}{l}.07^{* * *} \\
(.03)\end{array}$ & $\begin{array}{c}.08^{*} \\
(.04)\end{array}$ & $\begin{array}{c}.05 \\
(.04)\end{array}$ \\
\hline Salience of Gay Issues & $\begin{array}{l}-.16 \\
(.12)\end{array}$ & $\begin{array}{c}-.08 \\
(.16)\end{array}$ & $\begin{array}{c}.03 \\
(.14)\end{array}$ & $\begin{array}{c}.18 \\
(.21)\end{array}$ & $\begin{array}{c}-.06 \\
(.17)\end{array}$ \\
\hline \multicolumn{6}{|l|}{ Individual level variables } \\
\hline Income/Education Index & $\begin{array}{l}.75^{* *} \\
(.25)\end{array}$ & $\begin{array}{l}.87^{* *} \\
(.34)\end{array}$ & $\begin{array}{c}.10 \\
(.30)\end{array}$ & $\begin{array}{r}-.38 \\
(.45)\end{array}$ & $\begin{array}{c}.33 \\
(.36)\end{array}$ \\
\hline Intercept & $\begin{array}{c}-11.37^{* *} \\
(2.84)\end{array}$ & $\begin{array}{c}-14.02^{* *} \\
(3.82)\end{array}$ & $\begin{array}{c}-1.12 \\
(3.42)\end{array}$ & $\begin{array}{r}.89 \\
(5.03)\end{array}$ & $\begin{array}{r}-7.88^{*} \\
(4.05)\end{array}$ \\
\hline$R$-square & .85 & .80 & .82 & .74 & .70 \\
\hline Adjusted $R$-square & .83 & .77 & .79 & .70 & .66 \\
\hline Standard error & .10 & .18 & .14 & .29 & .19 \\
\hline$F$ Score & 40.76 & 27.92 & 32.35 & 20.15 & 16.96 \\
\hline $\begin{array}{l}\text { Probability of } F \\
N=50\end{array}$ & .0000 & .0000 & .0000 & .0000 & .0000 \\
\hline
\end{tabular}

Notes: Standard errors are in parentheses; significance levels: ${ }^{*} p<.05 ;{ }^{*} p<.10$

(HRC) is predicted best by the models, with at least 80 percent of the variation in membership explained. Gay and Lesbian Parents Coalition International (GLPCI) membership is the most poorly predicted, perhaps because it focuses on issues that involve parents and are not necessarily related to homosexuality.

Most importantly, membership in each group, except GLPCI, is positively associated with the Summed Membership of the other groups. This result lends support to the hypothesis that in accordance with the competitive exclusion principle, gay and lesbian groups avoid direct competition by partitioning space (members) through their adaptation to different issue niches. The finding is consistent with the implications of the population ecology theory suggested by Lowery and Gray (1995) and the findings of Gray and Lowery's (1996) test of niche theory. 
The measure of competition's lack of significance in the model of membership in GLPCI indicates that GLPCI's issue niche is so distinct from those of the other gay and lesbian interest groups that it does not have to share space with the other groups. GLPCI may attract gays and lesbians who do not feel well represented by other groups; as one might imagine, parents, gay or not, probably have different concerns from those of nonparents. The finding may also suggest that the most highly specialized interest groups in an issue area are least likely to be subject to the competitive exclusion principle and will, therefore, have no need to share space with other groups.

Same-gender partner households, the measure of Potential Constituency, is the most consistent significant predictor of membership in each group, indicating that space is an important factor in predicting interest group membership levels. The other measure of space, Summed Gay Institutions (gay community economic development), does not perform nearly so well; the measure is only significant in two of the models and indicates a negative relationship in one. While this may be the result of measurement error, it could also indicate that community economic development does not necessarily translate into political mobilization. The measure, however, is strongly significant in the model predicting GLVF membership. Because GLVF operates as a PAC and the other groups do not, it makes intuitive sense that economic development would matter most for the group most directly concerned about financial contributions. ${ }^{12}$

One measure of energy, antidiscrimination policy, performs quite well and shows significant positive influences on the membership of each group except GLPCI. This is likely the result of GLPCI's highly specialized issue concernsGLPCI members are more likely to be concerned about gay parenting issues that are not captured by my measure of lesbian and gay policy. The broader measure of energy, issue salience, did not perform well, failing standard significance tests. Lastly, the income and education index variable explains membership in NGLTF and LLDEF well but fails significance tests in the other models. Being the two oldest groups in the sample, NGLTF and LLDEF may have more experience in targeting potential members in states with higher income and education levels.

\section{CONCLUSIONS AND IMPLICATIONS}

Population ecology theory suggests that the environmental constraints of space and energy will determine membership levels in interest groups. The competition exclusion principle indicates that interest groups in competition for space (members) will share space by partitioning the issue area into separate issue niches.

The results of the analysis described above support the implications of the competitive exclusion principle - gay and lesbian interest groups avoid direct

\footnotetext{
${ }^{12}$ The costs of membership in the GLVF are considerably higher than for the other groups. GLVF members make an annual contribution of $\$ 100$ and also promise to donate at least another $\$ 200$ annually to specific candidates supported by the GLVF (data from GLVF).
} 
competition for space by sharing available space through adaptation into separate issue niches. This process allows each group to ensure its own survival without threatening the survival of groups working toward similar collective goods. ${ }^{13}$

The research presented here clearly demonstrates the implications and usefulness of population ecology theory for research on interest groups at the aggregate level. As Gray and Lowery (1996) suggest, the framework may even provide the much-needed bridge between interest group research at the individual and aggregate levels by accounting for the importance of environmental constraints. Future researchers can expand population ecology theory by considering the framework's implications for issue specialization over time, the role of large donors in this process, competition between groups lobbying at different levels of government, and how the process of issue specialization may influence the representativeness of interest groups.

Manuscript submitted 4 January 1996

Final manuscript received 22 fuly 1996

\section{REFERENCES}

Brown, Clyde. 1989. "Explanations of Interest Group Membership over Time." American Politics Quarterly 17:32-53.

Browne, William P. 1990. "Organized Interests and Their Issue Niches: A Search for Pluralism in a Policy Domain." Journal of Politics 52:477-509.

Gray, Virginia, and David Lowery. 1996. "A Niche Theory of Interest Representation." fournal of Politics 58:91-111.

Haider-Markel, Donald P., and Kenneth J. Meier. 1996. "The Politics of Gay and Lesbian Rights: Expanding the Scope of the Conflict." Fournal of Politics 58:352-69.

Haider-Markel, Donald P., and Kenneth J. Meier. N.d. "Legislative Victory; Electoral Uncertainty: Explaining Outcomes in the Battles over Lesbian and Gay Rights." Policy Studies Fournal. Forthcoming.

Hannan, Michael T., and Glenn R. Carroll. 1992. Dynamics of Organizational Populations. New York: Oxford University Press.

Hannan, Michael T., and John Freeman. 1989. Organizational Ecology. Cambridge, MA: Harvard University Press.

Hansen, John M. 1985. "The Political Economy of Group Membership." American Political Science Review 79:79-96.

Hunter, Kenneth G., Laura A. Wilson, and Gregory G. Brunk. 1991. "Societal Complexity and Interest-Group Lobbying in the American States." Journal of Politics 53:488-503.

Leighley, Jan E. 1995. "Attitudes, Opportunities and Incentives: A Field Essay on Political Participation." Political Research Quarterly 48:181-210.

Lowery, David, and Virginia Gray. 1993. "The Density of State Interest Group Systems." Journal of Politics 55:191-206.

${ }^{13}$ If space becomes limited in the future, gay and lesbian interest groups will be forced to adapt to more specialized issue niches or face direct competition with each other, possibly threatening the survival of some groups. 
Lowery, David, and Virginia Gray. 1994. "The Nationalization of State Interest Group System Density and Diversity." Social Science Quarterly 75:368-77.

Lowery, David, and Virginia Gray. 1995. "The Population Ecology of Gucci Gulch, or the Natural Regulation of Interest Group Numbers in the American States." American Fournal of Political Science 39:1-29.

Meier, Kenneth J. 1988. The Political Economy of Regulation: The Case of Insurance. Albany: State University of New York Press.

National Gay and Lesbian Task Force Policy Institute. 1993. Gay and Lesbian Rights in the U.S. Washington: National Gay and Lesbian Task Force Policy Institute.

Rosenstone, Steven J., and John M. Hansen. 1993. Mobilization, Participation, and Democracy in America. New York: Macmillan.

Tufte, Edward R. 1979. Data Analysis for Politics and Policy. Englewood Cliffs, NJ: Prentice-Hall.

U.S. Bureau of the Census. 1990. 1990 Census of Population Social and Economic Characteristics: United States. Vol. 1. Washington, DC: U.S. Bureau of the Census.

U.S. Bureau of the Census. 1992. Statistical Abstract of the United States: 1992. 112th ed. Washington, DC: L.S. Bureau of the Census.

Wald, Kenneth D., James W. Button, and Barbara A. Rienzo. 1996. "The Politics of Gay Rights in American Communities: Explaining Antidiscrimination Ordinances and Policies." American fournal of Political Science 40:1152-78.

Donald P. Haider-Markel. Ph.D. in political science, University of WisconsinMilwaukee, Milwaukee, WI 53201-0413. 